\title{
最適化問題としての文書要約
}

\section{Automatic Summarization as a Combinatorial Optimization Problem}

\author{
平尾 努 \\ 日本電信電話株式会社 NTT コミュニケーション科学基礎研究所 \\ NTT Communication Science Laboratories, NTT Corporation \\ hirao@cslab.kecl.ntt.co.jp \\ 鈴木 潤 \\ (同上) \\ jun@cslab.kecl.ntt.co.jp \\ 磯崎 秀樹 \\ (同上) \\ isozaki@cslab.kecl.ntt.co.jp
}

keywords: text summarization, sentence compression, combinatorial optimization, knapsack problem, dynamic programming

\begin{abstract}
Summary
We derived the oracle summary with the highest ROUGE score that can be achieved by integrating sentence extraction with sentence compression from the reference abstract. The analysis results of the oracle revealed that summarization systems have to assign an appropriate compression rate for each sentence in the document. In accordance with this observation, this paper proposes a summarization method as a combinatorial optimization: selecting the set of sentences that maximize the sum of the sentence scores from the pool which consists of the sentences with various compression rates, subject to length constrains. The score of the sentence is defined by its compression rate, content words and positional information. The parameters for the compression rates and positional information are optimized by minimizing the loss between score of oracles and that of candidates. The results obtained from TSC-2 corpus showed that our method outperformed the previous systems with statistical significance.
\end{abstract}

\section{1. は じめに}

一般的に,重要文抽出技術による要約に対しては,携帯 端末に表示する場合のように，厳しい文字数の制限が与 えられた場合 , 要約に含めることのできる文の数が極端 に少なくなるため，十分な情報を乥こに含めることがで きないという問題か指摘されている [Mani 01, 奥村 05] このため, 現在の自動要約システムは, 重要文抽出技術 (文への重要度付与) と文短縮技術を併用することで実現 されている場合が多い [Mani 01, 奥村 05] .

しかし, 文抽出と文短縮器を単純に組合せるだけでは， 限られたスペースに対し，採用できる文の数か増えたとし ても, 要約として重要な情報か増えるとは限らない，たと えば, 文献 [Lin 03]では, Lin らの重要文抽出器 [Lin 02] に対し，Knight らの文短縮器 [Knight 02] を組合せて要約 を生成*1 したところ,重要文抽出による要約よりも品質が 低下したことを報告している．また，文献 [Vanderwende 07] でも文短縮器が常に有効に働くとは限らないことを 報告している.このように，現状では文抽出と文短縮を 併用して要約を生成することの有効性は不明確である .

ここで, 人間が重要文抽出と文短縮を用いて要約を生

$* 1$ 真の意味での言語生成ではないことに注意されたい .
成する場合を考えてみよう、いま，重要文として下記の 3 文が抽出されており，これをさらにある文字数にまで 短縮しなければならないとする .

1. 8 月 7 日, 午前 10 時頃, 恵比寿駅で犬が線路に転落.

2. 山手線は現在運転を見合わせている.

3. この影響により，地下鉄全線にもダイヤの乱れが生 じている。

日時, 場所という情報が要約に必須であるとすると，1 文目は短縮することはできない． 2 文目からは,「現在 を削除することができる．3 文目からは，「この影響によ り」を削除することが可能であるし，文末表現として曖 昧さか残るものの「生じている」を削除することもでき る.もちろん，双方を削除することも可能である．

文字数制限が 65 文字であるとするならば， 1 文目，2 文目は原文を弚のまま用い，3文目を「この影響により， 地下鉄全線にもダイヤの乱れが 」や「地下鉄全線にもダ イヤの乱れが生じている.」にすれば良いであろう．さら に, 文字数制限が厳しくなり，55 文字であるとすると， 2 文目から「現在」を削除し，3文目を「地下鉄全線にも ダイヤの乱れが 」とすれば良いであろう.

この例から分かるように，人間は，すべての文を短縮 するわけではなく，短縮する文と光うでない文，短縮す る場合には, 要約率 (文字数制限), 文の重要度や文脈を 
考慮して，樣々な短縮を適切に使い分ける．

これは, 要約システムには, 文を要約に含めるか否か という判断と含めるのであれば光れをどの程度まで短縮 するのかという判断が必要であることを示唆している. すなわち, 文書中の各文に対し, 適切な文短縮率を設定 することの重要性を示唆している .

本稿では，まず，文抽出と文短縮を併用することて到 達可能な最大 ROUGE スコア [Lin 04] *2を保持するオラ クル要約を定義し, 少の分析に基づき, 要約システムに とって，文を短縮するか否かの判断だけでなく，乥れに 対し適切な短縮率を設定することの重要性を示す．次に， この問題を原文と光れに対応する樣々な長さの短縮文か らなる文集合から，文字数制限を満たし，かつ，文スコ アの和を最大化する組合せを選択する最適化問題として とらえ，動的計画法を用いて乥れを解決する手法を提案 する.オラクルの分析結果をふまえ, 文のスコアは, 乥 の出現位置, 単語重要度, 短縮率に基づき定義する.出 現位置と短縮率に関するパラメータは, オラクルのスコ アとシステムが出力する要約候補のスコアを用いて定義 する損失関数を最小化することで最適化する．

提案手法を Text Summarization Challenge (TSC) 2 [Okumura 03] コーパスを用いて評価実験を行ったところ，樣々 な文短縮率を組合せることで, 単なる重要文抽出による 要約システムよりも統計的に有意な差でROUGE スコア が向上することを確認した . また，TSC-2 参加システム と比較しても統計的に有意な差で優れていることも確認 した .これらより，樣々な文短縮率を適切に使い分ける ことの有効性を示した .

以下，2 章では, 文書要約における文短縮の有用性を 考察し，原文と光れに対応する複数短縮率による短縮文 を用意し，樣々な短縮率を組合せて要約を生成すること の意義を議論する. 3 章では， 2 章での議論に基づき文 のスコアを定義し，产の総和を最大化する文の組合せを 動的計画法を用いて求める手法を提案する. 4 章では， 評価実験の設定について述べ, 5 章て結果を考察する. 6 章では関連研究について述べる.

\section{2. 文書要約における文短縮の有用性}

\section{$2 \cdot 1$ オラクルの定義}

文短縮が文書要約に与える影響を調査するため，いわ ゆる重要文抽出のみで要約を生成した場合，ある固定の 短縮率で文を決定的に短縮した後, 要約を生成した場合 の双方に対し，参照要約に対する ROUGE スコアを調べ た。なお，文短縮器には文献 [平尾 08]の手法を用いた .

TSC-2 の訓練データ (30 文書， 1 文書あたり 3 参照要 約)を対象として，指定された文字数制限を満たす文の

*2 最も広く用いられている自動評価手法. 日本語においても， 人間の評価結果との相関は 0.9 程度あり, 十分に信頼性が高い [平尾 06]
表 1 TSC-2 の訓練データに対して得たオラクルの ROUGE スコア (固定の短縮率を用いた場合)

\begin{tabular}{l|ccccc}
\hline \hline \multirow{2}{*}{ 評価指標 } & \multicolumn{5}{|c}{ 文短縮率 } \\
& 1.0 & 0.9 & 0.8 & 0.7 & 0.6 \\
\hline ROUGE-1 & .612 & .587 & .580 & .580 & .568 \\
ROUGE-2 & .396 & .354 & .347 & .339 & .320 \\
ROUGE-SU & .418 & .378 & .369 & .359 & .340 \\
\hline 文数 & 133 & 144 & 164 & 180 & 213 \\
\hline
\end{tabular}

組合せをすべて探索し，ROUGE-2 スコア ${ }^{* 3}$ の平均 (3つ の参照要約に対する ROUGE-2 スコアの平均) を最大と する要約 (以下, オラクル)を求めた (式 (1)) .

$O=\underset{S}{\operatorname{argmax}} \frac{1}{3} \sum_{i=1}^{3} \operatorname{ROUGE}-2\left(S, H_{i}\right)$

$S$ は, 自動要約,$H_{i}$ は参照要約である . 文短縮率 ${ }^{* 4}$ は 1.0 0.6の 5 種を試した .

なお，この計算には, 文書中の文数を $N$ とすると， $2^{N}-1$ とおりの組合せの探索が必要となるが, 実際に は, 文字数制限を超える組合せをすべて無視できるので， 与えられた制限文字数が少ない場合, 文の短縮率が高い 場合には現実的な時間で探索を行うことができる.TSC-2 のデータには文字数に基づき, 約 $20 \%$ 要約率の参照要約 と 40\%要約率の参照要約が用意されているが, 紙面の都 合により，以下では, 20\%要約率の結果のみを示す．

\section{$2 \cdot 2$ オラクルから何を学ぶべきか}

文短縮率とオラクルの ROUGE スコア [Lin 04] , 文数 の関係を表 1 に示す .なお，ROUGE-SU におけるバイ グラムのスキップ幅は 4 単語に設定した .

表より，文の短縮率を下げると要約として選択できる 文の数か増える一方, ROUGE スコアは低下している，ど の短縮率においても単なる重要文抽出の場合よりもスコ アは低下しており，有意水準 $\alpha=0.05$ として，ウィルコ クソンの符号付順位和検定で検定したところ統計的に有 意な差であった (本稿では, 以降の検定にはすべて，有 意水準 $\alpha=0.05$ として, ウィルコクソンの符号付順位和 検定を用いた）。この結果は, 文を一律に短縮し，要約を 生成すると，参照要約に含まれる $\mathrm{N}$ グラムが保持できな くなることを示している．また，文短縮を用いることに よって文の数を増やすことが, 必ずしも要約として必要 な情報を増加させていないことも示している．

次に, 各文に対し, 原文に加え, 短縮率の異なるいくつ かの短縮文を用意し, 乥れらからオラクルを求めた .た だし, 短縮率のバリェーションを $|R|$ とすると, 文字数 制限を超える組合せは無視できるものの, $(1+|R|)^{N}$ と

\footnotetext{
*3 現状において最も広く用いられる自動評価指標が ROUGE-2 であることからこれを用いた

*4 短縮率は単語数に基づき計算する.
} 
表 2 TSC-2 の訓練データに対して得たオラクルの ROUGE スコア (複数短縮率を用いた場合)

\begin{tabular}{l|llllllllll}
\hline \hline \multirow{2}{*}{ 評価指標 } & \multicolumn{10}{|c}{ 短縮率の組合せ } \\
& 1.0 & $1.0+0.9$ & $1.0+0.8$ & $1.0+0.7$ & $1.0+0.6$ & $1.0+0.5$ & $1.0 \sim 0.8$ & $1.0 \sim 0.7$ & $1.0 \sim 0.6$ & $1.0 \sim 0.5$ \\
\hline ROUGE-1 & .612 & .619 & .622 & .628 & .626 & .629 & .622 & .632 & .634 & .635 \\
ROUGE-2 & .396 & .400 & .407 & .412 & .408 & .412 & .406 & .413 & .419 & .421 \\
ROUGE-SU & .418 & .422 & .428 & .429 & .427 & .430 & .426 & .432 & .437 & .438 \\
\hline 文数 & 133 & 136 & 138 & 142 & 150 & 150 & 138 & 143 & 144 & 147 \\
\hline 1.0 & 133 & 106 & 103 & 107 & 109 & 112 & 95 & 92 & 91 & 91 \\
0.9 & - & 30 & - & - & - & - & 13 & 13 & 13 & 12 \\
0.8 & - & - & 35 & - & - & - & 30 & 16 & 15 & 13 \\
0.7 & - & - & - & 35 & - & - & - & 22 & 13 & 12 \\
0.6 & - & - & - & - & 41 & - & - & - & 12 & 10 \\
0.5 & - & - & - & - & - & 38 & - & - & - & 9 \\
\hline
\end{tabular}

おり近い組合せを探索しなければならない .この探索は 現実的ではないため. 本稿では以下の手順でオラクルを 求めた . (1) 参照要約中の各文に対し, 原文と乥れらから 得た短縮文との間の ROUGE-2 スコアを求め, 上位 2 文 をプールしておく . (2) プールされた文集合に対してすべ ての組合せを探索し ROUGE スコアを求める . 先の実験 とは異なり，全組合せを探索していないため，正確な才 ラクルではない可能性があることに注意されたい .

短縮率の組合せについては，原文とある一定の短縮率 の 2 種を組合せる場合と組合せる短縮率を順に増やす場 合を試した . 兴の結果を表 2 に示す. 総文数に関しては， 各短縮率の文がオラクルに採用された数も示した .

表より，原文とある固定の短縮率を組合せるよりも複 数の短縮率を増やしつつ組合せた方が成績が良い，原文 と短縮率 0.5 を組合せた場合と，原文と 0.5 までの短縮率 を組合せた場合の間には統計的に有意な差があった . ま た , 短縮率のバリエーションを増やすと ROUGE スコア が向上する傾向にある．1.0～.0.5 までのすべての短縮率 の文を用いた場合，1.0のみを用いた場合と比較して，30 文書中 28 文書でスコアの向上か認められ，統計的に有 意な差でROUGE スコアが向上した .

オラクルに採用された文の数については表 1 とは異な り，1.0〜0.5 までのすべての短縮率を用いたとしても原 文のみで生成したオラクルとの差は 10 文程度でしかな い.また，オラクルに採用された全 147 文のうち 91 文 が短縮されていない文であった．つまり，才ラクルの約 6 割の文が短縮されていない原文である.他の短縮率の

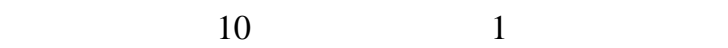

これらの結果は，原文兴のものを要約の候補として残 しておくことの重要性を示しており，文短縮器は，単純 に適用すれば良いものではないことを示している.つま り, 文書中の各文に対して, 弚れ光れ適切な短縮率を設 定したうえで文短縮器を用いなければ光の効果は期待で きない．

よって，原文のみを対象として要約を生成する手法，た

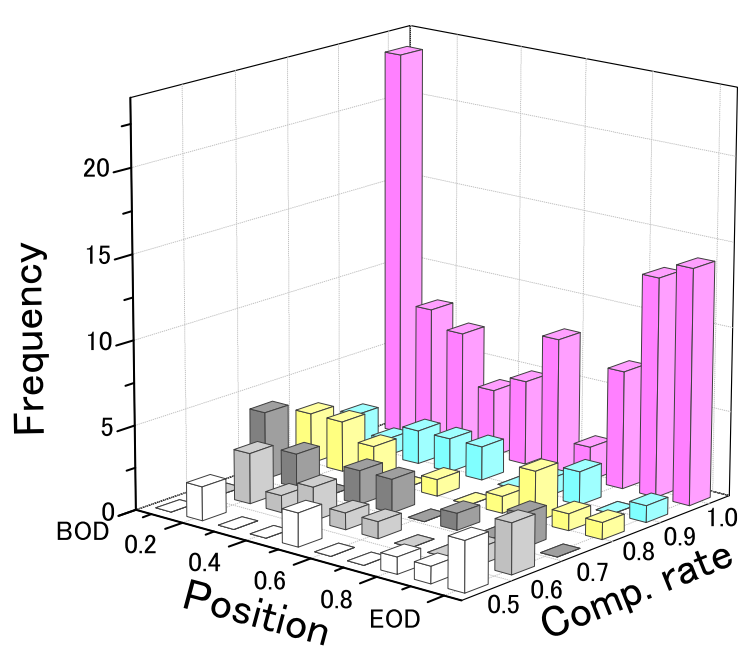

図 1 オラクルに選択された文の頻度と短縮率, 文書内部での位置 の関係

とえば，[McDonald 07]，原文とある特定の短縮率の文 を組合せを対象として要約を生成する手法 [Yih 07]，原 文をの艺く複数短縮率の文の組合せを対象として要約を 生成する手法 [Zajic 07] では, オラクルに到達すること は不可能である .

\section{3. 組合せ最適化問題としての文書要約}

前節でのオラクルの分析をふまえ，文書中の原文と複 数の短縮率で短縮した文に対しスコアを与えた後, 文字 数制限を満たし，かつ，スコアの和が最大となる文の組 合せを探索し，要約を生成する手法を提案する。

\section{$3 \cdot 1$ 短縮率と出現位置を考慮した文のスコアリング}

表 2 において最も ROUGE スコアが高いオラクル ,つ まり，文短縮率，1.0〜 0.5 までを用いたオラクルに関し て, 各短縮率における文の位置とオラクルに選択された 
文の頻度の関係を図 1 に示す．

図より, オラクルに選択された文の頻度傾向は, 短縮 率によって異なっている．たとえば，短縮率 1.0 の場合， 文書の先頭から $10 \% に$ にけてと末尾から $20 \%$ にかけて出 現する文が他の位置に出現する文よりもより多くオラク ルに採用されており，これらの位置に明確なピークが存 在する.一方, 他の短縮率では, 文書の半ば付近で選択 される文数が少ないことが共通するものの, 明確なピー クは存在せず, なだらかな分布である .これらは, オラク ルに選択される文の分布が, 兴の短縮率と出現位置に依 存していることを示しており，短縮率を反映した文のス コアリングの必要性を示している.乥こで, 短縮率 $r^{* 5}$ ご とに，出現位置を考慮した文のスコアを以下の混合正規 分布 ${ }^{* 6}$ を用いて定義する。

$$
\begin{aligned}
& g_{r}\left(k(i, D), \boldsymbol{\lambda}_{r}\right)= \\
& \sum_{j=1}^{J} m_{r}^{j} \frac{1}{\sqrt{2 \pi} \sigma_{r}^{j}} \exp \left(-\frac{1}{2}\left(\frac{k(i, D)-\mu_{r}^{j}}{\sigma_{r}^{j}}\right)^{2}\right)
\end{aligned}
$$

$i$ は,文書 $D$ における文のインデックスを表し,$k(i, D)$ は, $i$ 番目の文の相対出現位置を返す関数である. 混合 正規分布のパラメータ (分散, 平均, 混合比) は $\boldsymbol{\lambda}_{r}=$ $\left\{\mu_{r}^{j} \sigma_{r}^{j}, m_{r}^{j}\right\}_{j=1, \ldots, J}$ と表す.

なお，混合する正規分布のは，図 1 より $J=3$ に設定 した .

短縮率 $r$ で短縮した $i$ 番目の文 $s_{i, r}$ のスコアを式 (2) と笚語重要度 $w(t)$ を用いて以下の式で定義する。

$f\left(s_{i, r}, \boldsymbol{\lambda}_{r}\right)=g_{r}\left(k(i, D), \boldsymbol{\lambda}_{r}\right) \sum_{t \in s_{i, r}} w(t)$

ただし, $w(t)$ は文書 $D$ における単語 $t$ の出現頻度に 基づき以下の式で定義する .

$w(t)=\frac{t f(t, D)}{\sum_{t \in D} t f(t, D)}$

$t f(t, D)$ は, 単語 $t$ の文書 $D$ における出現頻度である.

\section{$3 \cdot 2$ 探索アルゴリズム}

文書 $D$ から選択した任意の文集合 $S$,すなわち要約の スコアを文のスコア $f\left(s_{i, r}, \boldsymbol{\lambda}_{r}\right)$ を用い，以下の式で定義 する .

$$
F(S, \boldsymbol{\Lambda})=\sum_{i} f\left(s_{i, r}, \boldsymbol{\lambda}_{r}\right)
$$

$* 5$ 以下, 短縮率の集合を $R$ とし, 乥の要素を $r$ とする.

*6 これ以外の関数でも分布を近似することは可能であるが, 後 に説明するパラメータの最適化の際，微分が必要になるので混 合正規分布を用いた。

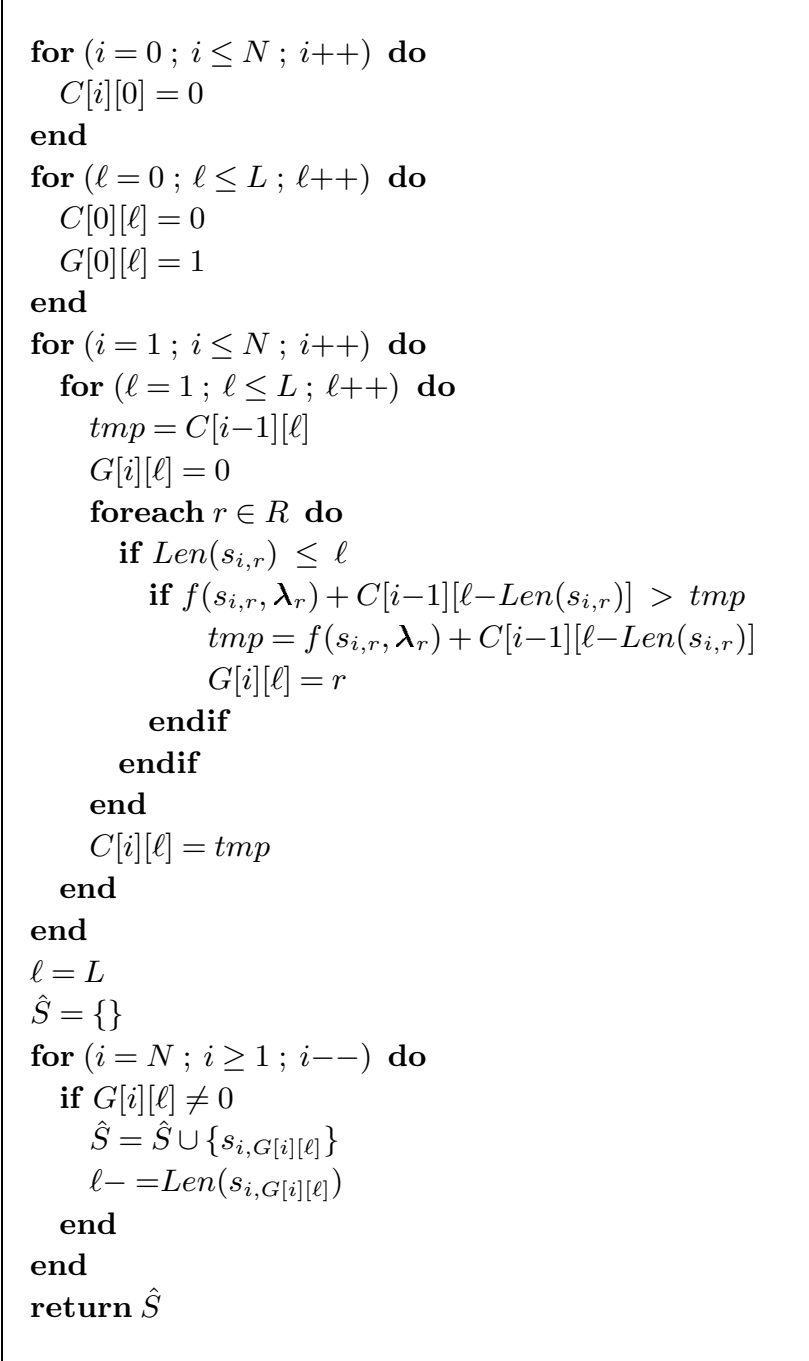

図 2 動的計画法を用いた要約の生成アルゴリズム

ただし， $\boldsymbol{\Lambda}=\left\{\left\{\boldsymbol{\lambda}_{r}\right\}_{r \in R}\right\}$ である.ここで，ある字数制 限 $L$ を満たし，なおかつ，式(5) を最大とする要約 $\hat{S}=$ $\underset{S}{\operatorname{argmax}} F(S, \boldsymbol{\Lambda})$, s.t. $\operatorname{Len}(S) \leq L$ を求めることはナップ サック問題としてとらえることができるので, 動的計画 法を用いて効率的に最適解を得ることができる．ただし， $\operatorname{Len}(\cdot)$ は, テキストの文字数を返す関数である.

图 2 に光のアルゴリズムを示す.$N$ は文書中の文の数， $C[i][\ell]$ は , $i$ 番目の文までを要約の候補とした場合にお ける文字数が $\ell$ 以下の要約のスコア $F(\cdot)$ の最大值を表 す.$R$ は, 文短縮率の集合, $r$ は弚の要素であり， $G[i][\ell]$

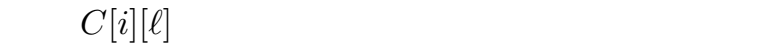

\section{$\mathbf{3} \cdot \mathbf{3}$ パラメータの最適化}

パラメータは, 正解である参照要約を再現するように 最適化すれば良い，一つの方法としては，参照要約と自 動要約のスコア $F()$ を用いて, 損失関数を定義し, 弚れ を最小化する問題と考えることか可能である .これは, 訓 練データ集合を $\mathcal{T}$ とした時, 以下の関数を最小化する問 
表 3 スコア関数と要約生成手法の比較 (TSC-2 テストデータ $20 \%$ 要約率

\begin{tabular}{l|ll|ll|ll}
\hline \hline \multirow{2}{*}{ 評価指標 } & \multicolumn{2}{|c|}{$\mathrm{tf}$} & \multicolumn{2}{c|}{$\mathrm{tf}$ pos } & \multicolumn{2}{c}{$\mathrm{tf}$ gauss } \\
& ranking & knapsack & ranking & knapsack & ranking & knapsack \\
\hline ROUGE-1 & .448 & .545 & .497 & .548 & .509 & $\mathbf{. 5 9 4}$ \\
ROUGE-2 & .225 & .261 & .260 & .290 & .284 & .354 \\
ROUGE-SU & .269 & .308 & .294 & .326 & .314 & $\mathbf{. 3 8 3}$ \\
\hline \multicolumn{7}{|c}{$40 \%$ 要約率 } \\
\hline ROUGE-1 & .640 & .663 & .642 & .662 & .652 & $\mathbf{. 6 7 8}$ \\
ROUGE-2 & .401 & .432 & .405 & .430 & .426 & $\mathbf{. 4 5 8}$ \\
ROUGE-SU & .432 & .460 & .434 & .456 & .455 & $\mathbf{. 4 8 4}$ \\
\hline
\end{tabular}

題として定式化できる .

$d(S, \boldsymbol{\Lambda})=\sum_{\tau \in \mathcal{T}} F\left(H_{\tau}, \boldsymbol{\Lambda}\right)-F\left(\hat{S_{\tau}}, \boldsymbol{\Lambda}\right)$

ただし， $\hat{S}$ は, 図 2 のアルゴリズムで求めた自動要約 である。しかし， $F(\cdot)$ は，文抽出と文短縮を併用して生 成した要約のスコアを計算するために設計した関数であ るため，人間がこれらの制約を受けずに自由に生成した 要約のスコアである $F\left(H_{t}, \boldsymbol{\Lambda}\right)$ を計算することはできな い.よって,式(6) を損失関数として用いることは不可能 である．しかし，本稿では，文短縮，文抽出のみによっ て生成されたオラクルを既に定義しているので，これを 用いることで，この問題を解決する．すなわち，以下を 損失関数として用いる.

$d(S, \boldsymbol{\Lambda})=\sum_{\tau \in \mathcal{T}} F\left(O_{\tau}, \boldsymbol{\Lambda}\right)-F\left(\hat{S_{\tau}}, \boldsymbol{\Lambda}\right)$

ただし， $O_{\tau} \neq \hat{S_{\tau}}$ である.ここで, 式 (7) を最小化す ることは, システム要約をオラクルに近づける効果が期 待できる.よって, 弚の結果として ROUGE スコアの向 上も期待できる .

式 (7) を弚のまま最小化することは難しいので平滑化 関数を用いた後に最小化を行う. 平滑化関数としてシグ モイド関数を用いると以下の関数を最小化する問題に帰 着する .

$L(d(S, \boldsymbol{\Lambda}))=\frac{1}{1+\exp (-c \times d(S, \boldsymbol{\Lambda}))}$

実際には勾配法を用いることで， $\Lambda$ の最適値を得るこ とができる、なお，このパラメータ最適化の考え方は, 基 本的には, 文献 [平尾 07] と同等である.

\section{4. 評価実験の設定}

\section{$4 \cdot 1$ コーパスと評価指標}

評価実験には，先述した TSC-2 データを用いた．毎日 新聞の社説，解説記事を対象としており，訓練 30 文書，
テスト 30 文書からなる . 各文書に対して 3 つの参照要約 が与えられており，光の要約率は文字数に基づき約 $20 \%$ ， 40\%である . パラメータの最適化には訓練用の 30 文書 を用い，評価指標には ROUGE-1，ROUGE-2，ROUGESU [Lin 04] を用いた . ROUGE-SU におけるバイグラム のスキップ幅は 4 単語とした .

ROUGE は , システム要約に出現する $\mathrm{N}$ グラムの頻度 分布が参照要約における光れと類似していると高い值を とり，完全一致する場合には，弚の值が 1 となる．

\section{$4 \cdot 2$ 文 短 縮 器}

文短縮器は, オラクル生成の際と同樣, 文献 [平尾 08] の手法を用いた . 以下に概要を説明する .

$\boldsymbol{x}$ を $N$ 個の単語からなる原文と考え $, \boldsymbol{x}=x_{1}, x_{2} \ldots, x_{i}$, $\ldots, x_{N}$ とする.$x_{j}$ は原文 $\boldsymbol{x}$ の $j$ 番目の単語である.つぎ に, $\boldsymbol{x}$ の部分単語列である短縮文を $\boldsymbol{y}=\left\{y_{1}, y_{2}, \ldots, y_{j}, \ldots\right.$, $\left.y_{M}\right\}$ とする.ただし,$y_{j} \in\left\{x_{1}, \ldots, x_{N}\right\}$ である . また， $x_{0}=y_{0}=<\mathrm{s}>, x_{N+1}=y_{M+1}=</ \mathrm{s}>$ とする .さらに,$y_{j}$ を原文における単語のインデックスへとマッピングする 関数として $I(\cdot)$ を導入すると, 短縮文 $\boldsymbol{y}$ のスコアは以下 の式で定義される

$$
\begin{array}{r}
\mathcal{F}(\boldsymbol{x}, \boldsymbol{y} ; \boldsymbol{W})=\sum_{j=1}^{M+1}\left\{\mathcal{G}\left(\boldsymbol{x}, I\left(y_{j}\right) ; \boldsymbol{w}_{g}\right)+\right. \\
\left.\mathcal{H}\left(\boldsymbol{x}, I\left(y_{j}\right), I\left(y_{j-1}\right) ; \boldsymbol{w}_{h}\right)\right\}
\end{array}
$$

ただし, $\boldsymbol{W}=\left\{\boldsymbol{w}_{g}, \boldsymbol{w}_{h}\right\}$ はパラメータベクトルである. $\mathcal{G}\left(\boldsymbol{x}, I\left(y_{j}\right) ; \boldsymbol{w}_{g}\right)$ は，短縮文に含まれる単語の重要度を表 し , Intra-sentence Positional Term Weighting (IPTW)に よって定義される. $\mathcal{H}\left(\boldsymbol{x}, I\left(y_{j}\right), I\left(y_{j-1}\right) ; \boldsymbol{w}_{h}\right)$ ，は短縮文中 での隣接する 2 単語の言語尤度を表し，Patched Language Model (PLM) で定義される . なお , パラメータ $(\boldsymbol{W})$ は， 正解短縮文に基づき，本稿でのパラメータの最適化の枠 組みと同じく, 誤り最小化 (MCE) 学習によって最適化さ れる . $\operatorname{argmax} \mathcal{F}(\cdot)$ とする短縮文 $\hat{\boldsymbol{y}}$ は動的計画法を用い て得ることができる . 
表 4 複数短縮率を組合せた場合の評価結果 (TSC-2 テストデータ) $20 \%$ 要約率

\begin{tabular}{|c|c|c|c|c|c|c|c|c|c|c|c|}
\hline & \multirow{2}{*}{$\begin{array}{l}\text { (a) } \\
1.0\end{array}$} & \multirow{2}{*}{\begin{tabular}{|l|} 
(b) \\
$0.8 \sim 0.5$
\end{tabular}} & \multicolumn{5}{|c|}{ (c) } & \multicolumn{4}{|c|}{ "(d):提案手法 } \\
\hline & & & $1.0+0.9$ & $1.0+0.8$ & $1.0+0.7$ & $1.0+0.6$ & $1.0+0.5$ & $1.0 \sim 0.8$ & $1.0 \sim 0.7$ & $1.0 \sim 0.6$ & $1.0 \sim 0.5$ \\
\hline ROUGE-1 & .594 & .541 & .597 & .599 & .600 & .599 & .601 & .599 & .601 & .603 & .604 \\
\hline ROUGE-2 & .354 & .264 & .355 & .356 & .357 & .356 & .356 & .357 & .359 & .360 & .360 \\
\hline ROUGE-SU & .383 & .306 & .384 & .385 & .386 & .385 & .386 & .386 & .388 & .389 & .389 \\
\hline \multicolumn{12}{|c|}{ 40\%要約率 } \\
\hline ROUGE-1 & .678 & .642 & .680 & .678 & .675 & .678 & .677 & .677 & .681 & .680 & .683 \\
\hline ROUGE-2 & .458 & .392 & .460 & .458 & .455 & .458 & .456 & .456 & .462 & .460 & .465 \\
\hline ROUGE-SU & .484 & .419 & .486 & .484 & .481 & .483 & .481 & .482 & .487 & .485 & .489 \\
\hline
\end{tabular}

\section{5. 実験結果と考察}

$5 \cdot 1$ 要約を組合せ最適化問題としてとらえることの有 効性とスコア関数の有効性

要約をナップサック問題として考えることの有効性と 提案したスコア関数の有効性を確かめるため, 重要文抽 出のみで要約を生成した場合の比較評価を行った .

式 (3) (ただし， $r=1.0$ のみ) を用いる場合 (tf*gauss) と, 式 (3) を以下に示す文書内での単語の出現頻度のみ に基づく場合 (tf : 式 (10))，位置情報を文番号の逆数で 与えた場合 (tf*pos：式 (11)) の光れ光れについて，f(·) で文をランキングした後，指定の文字数を満たすまで文 を選択して要約を生成した場合，図 2 に示したアルゴリ ズムを用いて文を選択して要約を生成した場合との比較 を行った . 兴の結果を表 3 に示す。

$f_{\mathrm{tf}}\left(s_{i, r=1.0}\right)=\sum_{t \in s_{i, r=1.0}} w(t)$

$f_{\mathrm{tf} * \operatorname{pos}}\left(s_{i, r=1.0}\right)=\frac{1}{i} \sum_{t \in s_{i, r}=1.0} w(t)$

表 3 より , どのスコア関数においてもナップサック問 題として要約を生成することで, ランキングによって要 約を生成する場合よりも ROUGE スコアが向上している . 关れ光れの差は, 統計的に有意であった . また, $\mathrm{tf*}$ gauss において , 要約のスコア $(F(\cdot))$ を計算したところ,ナッ プサックを用いると，ランキングの場合と比較して，光 のスコアは約 1.1 倍となった .

次に , スコア関数を比較すると ,ランキング, ナップサッ クの双方において，tf*gauss の成績が最も良い.20\%要

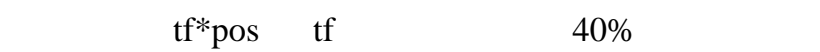
わずかな差であるが $\mathrm{tf}$ の方が良い .これより, 文の出現 位置情報を導入することは有効ではあるが，単純に文番 号の逆数として与えるだけは不十分であり, ガウス混合 分布を仮定し，訓練データを用いて产のパラメータを最 適化することで, 弚の有効性が発揮できることが分かる .
以上より , 要約をナップサック問題としてとらえるこ と, 提案した文のスコア関数の有効性を確認した .

\section{$5 \cdot 2$ 複数短縮率の文を用いることの有効性}

次に，原文だけでなく光れに対応する短縮文も要約生 成の対象とした場合の評価を行った . 要約を生成する際 の探索対象としては, 以下に示す組合せを比較した .

(a) 原文のみ

(b) 原文は用いずに複数短縮率の文

(c) 原文とある 1 種の短縮率の文

(d) 原文と複数短縮率の文

いま, 議論を簡単にするため, 文の重要度は, 提案手 法 (式(3))により与えられているとする .すると，探索対 象の違いから , (a) は MacDonald [McDonald 07] , (b) は Zajic ら [Zajic 07], (c) は Yih ら [Yih 07] の手法の変種 としてとらえることができる．ただし，Zajic らはランキ ングで要約を生成する手法を提案したが ,ここでは,ナッ プサックにより要約を生成した .

評価結果を表 4 に示す.なお，(c) に関しては, 最も成 績の良かった短縮率 $0.5 \sim 0.8$ の組合せの結果のみを示す．

表より，20\%要約率，40\%要約率ともに短縮率 1.0〜 0.5 までを用いた場合の成績が最も良いという点は共通 している.しかし，40\%要約率の場合，文短縮を用いた ことによるスコアの改善幅は小さい．これは，文字数制 限が緩和されると文短縮を用いなくとも多くの情報を要 約に採用できるため, 弚の効果が薄れることを示唆して いる . 本稿では, 要約システムは, より高圧縮で質の高 い要約を生成することか望ましいとの立場をとる．よっ て，以下では，20\%要約率の結果について議論する．

原文を探索対象から取り除いた (b) は, 明らかに ROUGE スコアが低い，原文のみで要約を生成した (a)よりもスコ アが大きく劣っていることから，原文を要約生成の対象 として含めることの重要性が分かる.これは, オラクル生 成の際に得た知見と良く合致している.次に，原文と短縮 文を組合せて要約を生成する際には，ある特定の短縮率 の文のみを組合せるのではなく，樣々な短縮率を組合せ た方が良い，(c)では，短縮率を変化させても，ROUGE 


\section{参照要約:}

3月期決算企業の株主総会が 29 日に開催のピークを迎える。上場する企業の $88 \%$ \%総会を開き、新社長や新取締役か誕生す る。しかし、本格的な景気回復には、民間需要の回復が不可欠だ。経営者が心掛けるべき第一は「選択と集中」である。史上最 高の利益を上げた約 80 社が、消費者のニーズをくみ取る能力に優れ、コアコンピタンス中心に事業展開している共通項があ る。昨年、米国の格付け会社がトヨタを引き下げた。世界標準や米国流経営の妄信は危険である。経営の原点は自己責任で、高 い志と倫理観を、総会を機に求めたい。

提案手法による要約 $(r=1.0$ のみ):

3 月期決算企業の株主総会が2 9 日に開催のピークを迎える。いまこ关企業家精神の出番なのである。右肩上がりの成長神話が 崩れた現在、経営者が第一に心掛けるべきは、「選択と集中」である。伸ばすべき分野と捨てる分野。内製化する分野と外部委託 する分野。選択したうえで、戦略部門に資源を集中投下する経営である。横並びの総花的経営に原因があることは明らかだ。経 営の原点は自己責任である。バブルのつけを国民の税金で処理する愚を繰り返してはならない。経営者に高い志と高い倫理観 を、株主総会を機に改めて求めたい。

提案手法による要約 $(r=1.0 \sim 0.5)$ :

3 月期決算企業の株主総会が2 9 日に開催のピークを迎える。総会では、多くの新社長が誕生する。いまこ光企業家精神の出番 なのである。右肩上がりの成長神話が崩れた現在、経営者が第一に心掛けるべきは、「選択と集中」である。選択したうえで、戦 略部門に資源を集中投下する経営である。横並びの総花的経営に原因があることは明らかだ。自由には高い規律が要求される。 経営の原点は自己責任である。バブルのつけを国民の税金で処理する愚を繰り返してはならない。経営者に高い志と高い倫理観 を、株主総会を機に改めて求めたい。

スコアの変化は小さい，一方，提案手法では，短縮率の 数を増やすことで ROUGE スコアが向上している．短縮 率を 0.5 まで用いた場合では，ROUGE-2，ROUGE-SU スコアは 0.6 までの短縮率を用いた場合と同等であるが， ROUGE-1 スコアは最も良い成績であった . 短縮率 1.0〜 0.5 と (a) とを比較するとすべての評価指標において, 統 計的に有意な差であった .

また，TSC-2て最も良い成績を残したシステム [Sakai 03]のROUGE スコアを計算したところ ,ROUGE-1=0.559 ， ROUGE-2=0.307 , ROUGE-SU=0.343 であった . このシ ステムでは, 文の短縮率は考慮せず, 名詞, 動詞の多重 修飾部を可能な限り削除する文短縮手法を採用している． よって，すべての文が短縮されるわけではなく，短縮さ れない文も存在する . ROUGE スコアは (a)よりも低く， 文短縮を用いた効果か現れていない .

これらより，原文に加え，複数短縮率の文を用いるこ との有効性が分かった . さらに, 提案手法が, 既存の要 約システムと比較して十分に良いことも分かった．

図 4 に, 文短縮率を $1.0 〜 0.5$ まで用いて学習したパラ メータによる混合正規分布 (式(2))を示す. 文書の先頭 , 末尾のスコアが高く , 文書の半ばにややスコアが高い部 分があることと 1.0 のスコアが他の短縮率より高いこと はオラクルの分析結果と良く合致している．

さらに，参照要約，(a)，(d)による要約を图 3 に示す． なお，参照要約に含まれる情報を持つ文は太字で示した 。 (d)，(a)で採用できなかった短縮文，『総会では、多くの 新社長か誕生する。』という文 (原文 :『総会では、多く の新社長や新取締役か涎生する。』）を採用できたことに より,「総会」,「新社長」,「誕生」という単語を要約に含 めることができている．また，短縮文を採用したことに よる改悪, すなわち, (a) では保持できていた参照要約に

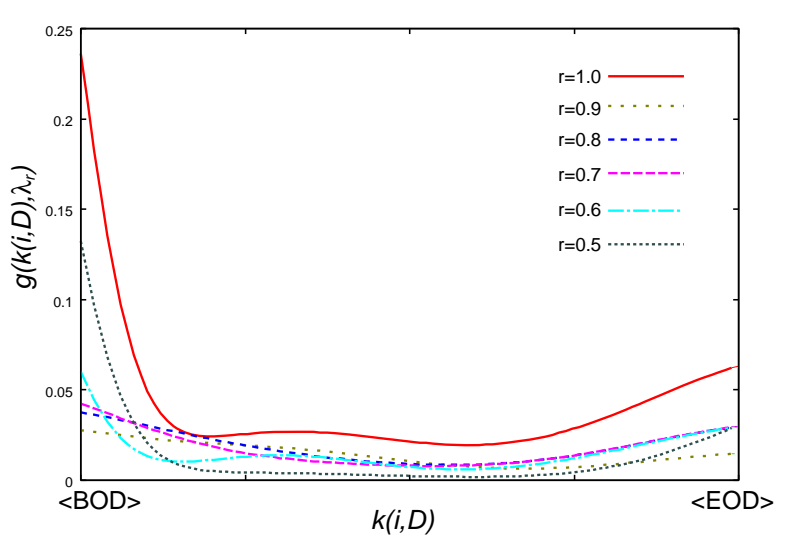

図 4 学習されたパラメータによる混合正規分布

含まれる単語列の欠落は生じていない，つまり，提案手 法には，短縮文を採用することで，参照要約に含まれる 単語列を増加させる働きがあることを示している．

\section{$5 \cdot 3 \mathrm{~N}$ ベスト解の有効性}

文献 [平尾 08] の文短縮手法は, 後向き $\mathrm{A} *$ アルゴリズ ム [Nagata 94] を適用することで効率的に N ベスト短縮 文を得ることができる．各短縮率に対してNベスト解を 出力することで, 要約として生成できる文の組合せが多 くなるのでROUGE スコアの向上か望める . 乥こで, (d) (短縮率は，1.0 0.5) と (c) (短縮率は, $1.0+0.8)^{* 7}$ に対し， 1 ベストから 10 ベスト解を採用した場合の性能を調べ た。弚の結果を表 5 に示す.

表より，どちらの手法も 6 ベスト，7 ベストまで採用 した場合に最も良い成績となった，双方とも 1 ベストの

*7 表 4 では 1.0+0.5 の組合せの成績が最も良いが $\mathrm{N}$ ベスト解を 導入した場合は，1.0+0.8の成績が最も良かった . 
表 $5 \mathrm{~N}$ ベスト解を用いた場合の ROUGE スコアの変化 (TSC-2 テストデータ: 20\%要約率)

\begin{tabular}{l|lll|lll}
\hline \hline \multirow{2}{*}{ N-best } & \multicolumn{3}{|c|}{$(\mathrm{c})$} & \multicolumn{3}{c}{$(\mathrm{d})$} \\
& ROUGE-1 & ROUGE-2 & ROUGE-SU & ROUGE-1 & ROUGE-2 & ROUGE-SU \\
\hline 1 & .599 & .356 & .385 & .604 & .360 & .389 \\
2 & .599 & .356 & .385 & .604 & .359 & .388 \\
3 & .599 & .356 & .386 & .606 & .360 & .389 \\
4 & .599 & .357 & .386 & .606 & .361 & .390 \\
5 & .600 & .357 & .386 & .607 & .362 & .391 \\
6 & .602 & .360 & .389 & .609 &. $\mathbf{3 6 4}$ & .393 \\
7 & .602 & .360 & .389 & .610 & .364 & .393 \\
8 & .602 & .359 & .388 & .608 & .362 & .392 \\
9 & .602 & .359 & .388 & .609 & .363 & .392 \\
10 & .602 & .359 & .388 & .608 & .362 & .391 \\
\hline
\end{tabular}

場合と比較すると統計的に有意な差であった．また，(c) がどの場合においても (d) の成績を上回ることはない .

以上より, 複数の短縮率を変化させるだけでなく，各 短縮率において Nベスト解を用いて候補を増やすことが 有効であることが分かった .ただし，8ベストを超える と性能が劣化していることから，候補数を増やしすぎる と悪影響が生じることも分かる.

\section{6. 関連研究との比較}

文献 [McDonald 07] では，原文のみを対象とし，文の スコアをTF.IDF 法によって決定し，ある文字数制限のも と, 弚の和を最大とする文の組合せをナップサックアル ゴリズムで探索する手法が提案されている．また，文献 [德永 00]では，文ではなく文節を対象とし，ナップサッ クアルゴリズムを適用する手法が提案されている．前者 には，原文のみを対象として要約を生成する点，後者に は，文節の抽出では要約の可読性か著しく低下するとい う点に問題がある。

一方, 文短縮器を利用して要約を生成する手法として は, Zajic らの手法 [Zajic 07] と Yih らの手法 [Yih 07]が ある.前者は, 原文に対し, 複数の短縮率と $\mathrm{N}$ ベスト解 を組合せ，多数の候補を用意した後，樣々な素性に基づ く関数で关れらをランキングし, 指定の文字数を満たす まで文を選択し，要約を生成する。提案手法は，彼らの 提唱する MCR (Multiple CandidateReduction), 多数の候 補から文を選択するという枠組みの自然な拡張といえる． 違いは，原文を要約生成の候補として用いるか否かとい う点, スコア関数と乥のパラメータ最適化法, 要約生成 のための探索手法にある. 実験結果で示したように，原 文を探索対象としていないこと，探索の手法として組合 せ最適化の考えか導入されていないことに問題がある．

後者は，原文とある短縮率の文を用意し，弚れらから 重要語を最大限カバーするような文の組合せをスタック デコーダーを用いて選ぶ . スタックデコーダのアルゴリ ズムは本稿で提案したナップサック問題を解くアルゴリ
ズム (図 2) と類似しているが, 原文と 1 種の短縮率で短 縮した文のみを候補としており, 異なる複数の短縮率を 利用していない点に問題がある.さらに, 彼らの目的関 数は, 重要語を最大限カバーすることにあるが, これは, 最終的にシステムを評価する ROUGE を最大化するとは 限らない，以上より，提案手法は原文に加え，複数の短 縮率で短縮した文を候補として要約を生成する点，オラ クルに基づき , パラメータを最適化するという点におい て既存の研究とは大きく異なる .

\section{7. ま め}

本稿では，まず，文抽出と文短縮を併用して到達する ことのできる上限として , オラクルを定義し, 光れに到 達するため, 各文に対し, 短縮しないということも含め, 最適な文短縮率を設定する必要があることを述べた 、次 に，これを原文と光れに対応する複数短縮率の短縮文か らなる文集合から弚のスコアを最大化し，かつ，文字数 制限を満たす組合せを選択する最適化問題 , ナップサッ ク問題としてとらえ，動的計画法を用いて光れを解く手 法を提案した · 文のスコアは , オラクルの分析に基づき， 短縮率, 出現位置, 単語出現頻度に基づき定義した。さ らに，位置情報に関するパラメータは，才ラクルとシス テム要約のスコアを用いて定義した損失関数を最小化す ることで最適化を行った .

TSC-2 コーパスを用いて評価実験を行った結果，提案 手法が , 従来手法よりも統計的に有意な差で優れている ことを確認した 。

\section{$\diamond$ 参 考 文 献 $\diamond$}

[Knight 02] Knight, K. and Marcu, D.: Summarization Beyond Sentence Extraction, Artificial Intelligence, Vol. 139, No. 1, pp. 91-107 (2002)

[Lin 02] Lin, C.-Y. and Hovy, E.: From Single to Multi-document Summarization: A Prototype System and its Evaluation, in Proc. of the 40th Annual Meeting of the Association for Computational Linguistics, pp. 457-464 (2002) 
[Lin 03] Lin, C.-Y.: Improving Summarization Performance by Sentence Compression - A Pilot Study, in Proc. of the 6th International Workshop on Information Retrieval with Asian Language, pp. 1-8 (2003)

[Lin 04] Lin, C.-Y.: ROUGE: A Package for Automatic Evaluation of Summaries, in Proc. of Workshop on Text Summarization Branches Out, pp. 74-81 (2004)

[Mani 01] Mani, I.: Automatic Summarization, J. Benjamins Pub. Co. (2001)

[McDonald 07] McDonald, R.: A Study of Global Inference Algorithms in Multi-document Summarization, in Proc. of the 29th European Conference on Information Retrieval, pp. 557-564 (2007)

[Nagata 94] Nagata, M.: A Stochastic Japanese Morphological Analyzer Using a Forward-DP Backward-A* N-Best Search Algorithm, in Proc. the 15th International Conference on Computational Linguistics, pp. 201-207 (1994)

[Okumura 03] Okumura, M., Fukusima, T., and Nanba, H.: Text Summarization Challenge 2: Text summarization evaluation at NTCIR Workshop 3, in Proc. of the the HLT-NAACL 03 Text Summarization Workshop (2003)

[Sakai 03] Sakai, H. and Masuyama, S.: Unsupervised acquisition of knowledge about the abbreviation possibility of some of multiple phrases modifying the same verb/noun, in Proc. of the NTCIR-3 (2003)

[Vanderwende 07] Vanderwende, L., Suzuki, H., Brockett, C., and Nenkova, A.: Beyond SumBasic: Task-focused summarization with sentence simplification and lexical expansion, Information Processing and Management, Vol. 43, No. 6, pp. 1606-1618 (2007)

[Yih 07] Yih, W.-T., Goodman, J., Vanderwende, L., and Suzuki, H.: Multi-Document Summarization by Maximizing Informative Content-Words, in Proc. 20th International Joint Conference on Artificial Intelligence, pp. 1776-1782 (2007)

[Zajic 07] Zajic, D., Dorr, B., Lin, J., and Schwartz, R.: Multicandidate reduction: Sentence Compression as a tool for document summarization, Information Processing and Management, Vol. 43, No. 6, pp. 1549-1570 (2007)

[奥村 05] 奥村 学, 難波 英嗣:テキストの自動要約, オーム社 (2005)

[德永 00] 徳永 秀和, 青江順一: 携帯電話情報サービスのための 新聞記事要約の研究, 情報処理学会研究報告 自然言語処理研究 会 (SIG-NL-140), pp. 17-22 (2000)

[平尾 06] 平尾 努, 奥村 学, 磯崎 秀樹 : 拡張ストリングカーネル を用いた要約システム自動評価法, 情報処理学会論文誌, Vol. 47, No. 6, pp. 1753-1766 (2006)

[平尾 07] 平尾努, 鈴木 潤, 磯崎 秀樹: 識別学習による組合せ最適 化問題としての文短縮手法, 人工知能学会論文誌, Vol. 22, No. 6A, pp. 574-584 (2007)

[平尾 08] 平尾努, 鈴木 潤, 磯崎 秀樹 : 軽量な文短縮手法, 言語処 理学会第 14 回年次大会, pp. 484-487 (2008)

〔担当委員 : 高山 泰博〕

2008 年 9 月 4 日 受理

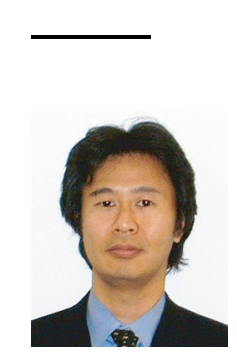

\section{者 紹}

平尾努

1995 年関西大学工学部電気工学科卒業. 1997 年奈良先端 科学技術大学院大学情報科学研究科博士前期過程修了. 同 年,(株) NTT データ入社. 2000 年より, NTT コミュニ ケーション科学基礎研究所に所属. 博士 (工学) . 自然言 語処理の研究に従事. 情報処理学会, 言語処理学会, ACL 各会員.

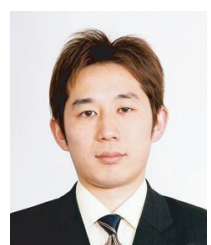

鈴木 潤

1999 年慶應義塾大学理工学部数理科学科卒業. 2001 年同 大学院理工学研究科計算機科学専攻修士課程修了. 同年, 日本電信電話株式会社入社 . 現在 , NTT コミュニケーショ ン科学基礎研究所に所属. 博士 (工学) . 主として自然言 語処理, 機械学習に関する研究に従事. ACL, 情報処理学 会, 言語処理学会各会員.

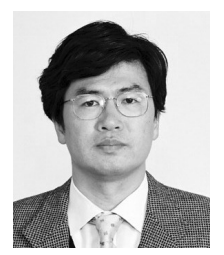

磯崎 秀樹(正会員)

1983 年東京大学工学部計数工学科卒業. 1986 年同工学 系大学院修士課程修了. 同年, 日本電信電話 (株) 入社。 1990 91 年スタンフォード大学ロボティクス研究所客員 研究員. 現在, NTT コミュニケーション科学基礎研究所 知識処理研究グループリーダ. 博士 (工学). 平成 15 年 度情報処理学会論文賞・山下記念研究賞受賞. 人工知能. 自然言語処理の研究に従事。電子情報通信学会, 情報処理 学会, 言語処理学会, ACL 各会員. 